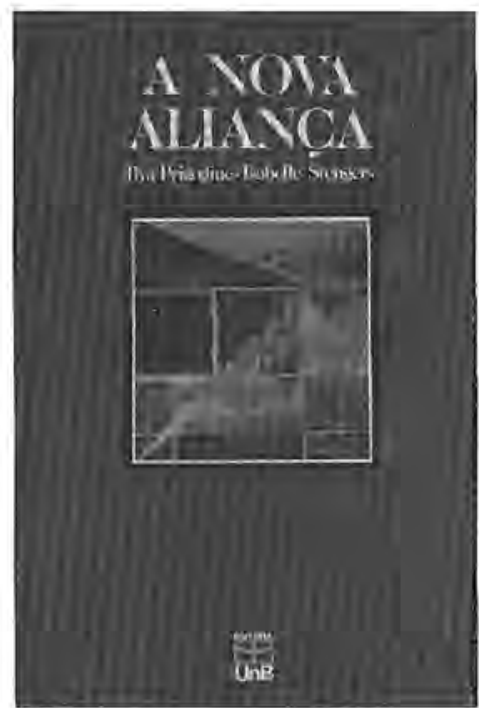

\section{A NOVA ALIANÇA: METAMORFOSE DA CIÊNCIA}

\section{de ILYA PRIGOGINE \& ISABELLE STENGERS}

Brasilia: Universidade de Brasilia, 1991, 247 p.

Tradução brasileira de La Nouvelle Alliance: metamorphose de la science por

Miguel Faria e Maria Joaquina Machado Trincheira.

por Thomaz Wood, Jr., Engenheiro Químico pela UNICAMP, Mestre e Doutorando em Administração de Empresas na EAESP/FGV.

D ara conhecer a História geralmente recorremos a enciclopédias. Mas há mais História em Tolstoi, Conrad e Stendhal que nos livros didáticos. E não é difícil entender o porquê. Estes grandes autores vivenciaram sua época, e o fizeram com grande sensibilidade, conseguindo transmitir, através de sua obra, o que de mais profundo caracteriza um período histórico, a forma de sentir e compreender o mundo ao redor. Os enciclopedistas são capazes de narrar e encadear fatos. Os artistas são capazes de senti-los e decifrá-los.

Assim é com a Análise Organizacional, esta quase ciência que tenta compreender este produto típico da modernidade que é a Organizaçăo.

É num contexto análogo a este que se insere este livro de Ilya Prigogine e Isa- belle Stengers, que nos chega oito anos após a edição original.

Prigogine, prémio Nobel de Química em 1977 por seu trabalho sobre a termodinâmica de sistemas afastados do equilíbrio, é um cientista com interesses multidisciplinares, da arqueologia à química, das artes à história. Stengers, a co-autora do livro, é filósofa e estudiosa da história da ciència.

Para Alvin Tofler, que prefaciou a edição americana - de 1984 - Prigogine é um dos homens que contraria a tendência contemporậnea ocidental da "dissecação" - $a$ arte de dividir as coisas nas suas menores partes para depois analisá-las. Este cientista, ao contrário, dedica sua vida a juntar de novo as peças no lugar e compreender holisticamente os fenômenos.

Seu trabalho aponta para o que se está convencionando chamar de Paradigma da Complexidade, uma confluência de idéias e conceitos vindos da Biologia, da Física, da Termodinâmica e da Cibernética, capazes de gerar uma nova forma de compreensâo dos sistemas organizacionais. O Paradigma da Complexidade, no seu contexto mais global, corresponde a uma nova percepção dos fenômenos organizacionais, capaz de penetrar na profunda rede de paradoxos, ambigüidades e conflitos que constituem as organizaçōes.

Neste livro, os autores argumentam que a tradicional visão da ciência da "idade da máquina", que enfatiza uniformidade, ordem e equilíbrio, está superada. Em seu lugar, propôe uma vasta síntese que engloba tanto sistemas em equilíbrio quanto sistemas distantes do equilíbrio.

Através de modelos de mudança qualitativa, Prigogine e Stengers lançam novas luzes sobre a Análise Organizacional. Seu trabalho aponta o modelo dominante para o presente e para o futuro, colocando o homem não em oposição, mas em comunicação com a natureza, numa visão de um mundo espontâneo e de auto-organizaçāo.

Tradicionalmente, o enfoque em mudança se faz através de modelos incrementais e de equilíbrio, baseados em adaptação lenta e pequenos ajustes. Mas esta visão não parece adequada à compreensão de sistemas complexos, especialmente quando mudanças mais radicais, globais, ocorrem. 
Prigogine estudou sistemas químicos não lineares, afastados do equilíbrio, onde a instabilidade e a desordem levam a novas formas de comportamento, novos padrões de interação e novas estruturas. Ele demonstrou que instabilidade, desordem e imprevisibilidade são fatores centrais no desenvolvimento de novas formas complexas de organização. Estes sistemas são estruturas dissipativas, compostas por uma variedade de subsistemas que interagem de forma não linear, tanto interna quanto externamente.

Sistemas normalmente importam e transformam energia em trabalho. Esta dinâmica, que também inclui a exportação de entropia, evita o declínio e a degeneração. Os sistemas não lineares alternam períodos de comportamento previsível com períodos de flutuaçôes randômicas, com perturbações internas e externas, que amplificam as interações nào lineares.

A continuidade deste processo pode levar o sistema além das fronteiras de estabilidade, a um ponto crítico, chamado de bifurcação, onde a simetria da estrutura existente é rompida. Isto inicia um estado dominado pela randomicidade e imprevisibilidade, caracterizado pelo comportamento caótico das estruturas dissipativas. Este estado possibilita explorar uma variedade de possibilidades evolucionárias.

Os autores observaram que existe uma preferência dos sistemas nestas condições por determinados caminhos, entre todos os possíveis. Existe um potencial de auto-organização, do sistema criar uma nova forma mais avançada de estrutura. O contrário seria o caos contínuo. Atingida esta nova estrutura, ela é mais complexa e mais capaz de realizar trabatho e atividade que a anterior. Isto devese a sua maior capacidade de atrair, utilizar e organizar a energia disponivel para a manutenção e evolução. Portanto, eventos de quebra de simetria são episódios críticos na evoluçāo.

Transposto para o estudo de organizações complexas, os conceitos desenvolvidos por Prigogine representam uma terceira onda de compreensão da dinâmica das mudanças. A primeira onda estaria baseada na visão da organização como máquina - própría do enfoque weberiano da organização burocrática - e em modelos de sistemas fechados, algoritmos e no princípio da minimizaçào da incerteza. A segunda onda estaria ligada à idéia da manutençăo do equilíbrio existente. É a visão das ciências sociais contemporâneas, dos sistemas adaptativos, interativos, adequando-se através de mudanças incrementais e tendo a estabilização em um novo patamar como meta. A terceira onda, então, admitiria a instabilidade dinàmica, mudanças descontínuas. Períodos de caos seriam uma condição necessária para a evoluçẫo.

A Nova aliança é um livro brilhante. Vale a pena enfrentar suas passagens mais áridas. A recompensa é uma nova forma de entender a conturbada dinâmica das mudanças que hoje vivemos, indo além da superfície que uma certa literatura atual costuma apresentar. 7

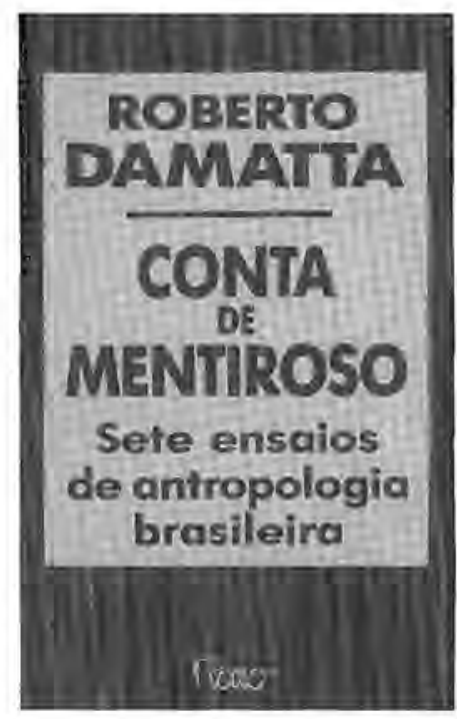

\section{CONTA DE MENTIROSO}

\section{de ROBERTO DaMATTA}

Rio de Janeiro; Rocco, 1993, 209 p.

por Roberto Venosa, Professor do Departamento de Administraçāo Geral e Recursos Humanos da EAESP/FGV.

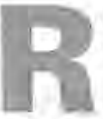
esenhar um livro escrito por Roberto DaMatta não deve, em princípio, ser tarefa difícil para ninguém. DaMatta é autor consagrado, intelectual respeitado e antropólogo com 